\title{
Erratum to: Colorimetric Glucose Assay Based on Magnetic Particles Having Pseudo-peroxidase Activity and Immobilized Glucose Oxidase
}

\author{
Pavla Martinkova $^{1} \cdot$ Radka Opatrilova $^{2} \cdot$ Peter Kruzliak $^{2} \cdot$ Igor Styriak $^{3}$ • \\ Miroslav Pohanka ${ }^{1}$
}

Published online: 22 June 2016

(C) Springer Science+Business Media New York 2016

\section{Erratum to: Mol Biotechnol (2016) 58:373-380 \\ DOI 10.1007/s12033-016-9936-Z}

In the original publication of the article, the affiliation associated with the author Peter Kruzliak was submitted and published incorrectly. The corrected affiliation as follows:
Department of Chemical Drugs, Faculty of Pharmacy, University of Veterinary and Pharmaceutical Sciences, Brno, Czech Republic.

This has been corrected with this erratum.

The online version of the original article can be found under doi:10.1007/s12033-016-9936-z.

Peter Kruzliak

kruzliakpeter@gmail.com

$\triangle$ Miroslav Pohanka

miroslav.pohanka@gmail.com

1 Faculty of Military Health Sciences, University of Defence, Trebesska 1575, Hradec Kralove 500 01, Czech Republic

2 Department of Chemical Drugs, Faculty of Pharmacy, University of Veterinary and Pharmaceutical Sciences, Brno, Czech Republic

3 Institute of Geotechnics, Slovak Academy of Sciences, Kosice, Slovak Republic 